\title{
Evaluation of columns according to gender and women's education
}

\author{
Demet ÇELIKK**
}

\author{
Meral UYSAL ${ }^{* * *}$
}

\begin{abstract}
This study is done in order to evaluate the columns of four national newspapers that are published in Turkey in respect of their messages about gender and women's education. All columns published in a year in Hürriyet, Radikal, Birgün and Zaman newspapers are regarded as the population, and 1620 columns, which are chosen as the sample of this population, are analyzed in line with the previously determined categories. In the end, it is seen that the columns of the newspapers exhibit sexist approaches in various ratios in concern with their political views.
\end{abstract} Analysis.

Keywords: Gender, Women's Education, Columns, Content

\footnotetext{
* Unpublished Master's Thesis, Ankara University, Graduate School of Educational Sciences, Department of Life Long Learning and Adult Education, Ankara, Turkey.

${ }^{* *}$ Doctoral Student, Ankara University, Faculty of Educational Sciences, Department of Life Long Learning and Adult Education, Ankara, Turkey. E-mail: dimetta@hotmail.com

Prof. Dr., Ankara University, Faculty of Educational Sciences, Department of Life Long Learning and Adult Education, Ankara,Turkey. E-mail: muysal@ankara.edu.tr
} 


\section{SUMMARY}

Purpose and Significance: This study is done in order to evaluate the columns in four national newspaper published in Turkey according to gender and women's education.Since newspaper is a kind of mass media, and that the columns published here can affect public's attitude of mind and behaviours, and also contribute to public's education, the messages given in the columns of newspapaer have been the object for the study.

Method: The study, in which method of content analysis is used, is restricted to the columns published in Hürriyet, Radikal, Birgün and Zaman newspapers between 01.01.2006-31.12.2006.All columns published in the above-mentioned newspapers in a year are regarded as the population, and 1620 columns, which are chosen as the sample of this population, are analyzed in line with the previously determined categories.

Results: In Zaman Newspaper, strict sexist attitudes toward women are seen and women's education and her general position are expressed by explanations that have religious motives. In Hürriyet, comments that relatively support gender equality by mentioning subjects such as being comfortable in public life, working or having education are faced. However, this situation is approved on condition that she carries on her traditional roles. In Hürriyet, the reasons of inequality between the sexes are not examined thoroughly and the thought of equality is grounded with regard to the necessity of being a modern society. In Radikal, on the other hand, in accordance with secular and leftist discourse, women's rights, women's education, and uprising women's social statue is highlighted and no sexist messages are came across.In Birgün Newspaper, no sexist discourse is faced and generally, the messages about the equality of the sexes and that the women are exploited in social and in-house fields are drawn attention.

Discussion and Conclusions: In general, in all the chosen four newspapers, sexist tendencies are determined in various ratios and it is observed that each newspaper perceives the phenomena of women's education according to their own perspective. 


\title{
Köşe Yazllarının Toplumsal Cinsiyet ve Kadın Eğitimi Açısından Değerlendirilmesi"
}

\author{
Demet ÇELIKK**
}

Meral UYSAL ${ }^{* * *}$

ÖZ. Bu çalışma, ülkemizde yayımlanan dört ulusal gazetedeki köşe yazılarının toplumsal cinsiyet ve kadın eğitimi konularında verdikleri mesajların değerlendirilmesi amacıyla yapılmıştır. Hürriyet, Radikal, Birgün ve Zaman gazetelerinde bir yıl içinde yayımlanan tüm köşe yazıları evren olarak kabul edilmiş, bu evrenden örneklem olarak alınan toplam 1620 köşe yazısı, önceden belirlenen kategoriler doğrultusunda içerik analizine tabi tutulmuştur. Sonuçta, her bir gazetenin kendi politik bakış açısı doğrultusunda ve değişen oranlarda cinsiyetçi yaklaşımlar sergiledikleri gözlenmiştir.

Anahtar Sözcükler: Toplumsal cinsiyet, kadın eğitimi, köşe yazıları, içerik analizi.

\footnotetext{
*Yayımlanmamış Yüksek Lisans Tez Özeti, Ankara Üniversitesi Eğitim Bilimleri Enstitüsü. ** Doktora Öğrencisi, Ankara Üniversitesi Eğitim Bilimleri Enstitüsü, Yaşam Boyu Öğrenme ve Yetişkin Eğitimi Anabilim Dalı Halk Eğitimi Bölümü, Ankara, Türkiye. E-posta:dimetta@hotmail.com

** Prof. Dr., Ankara Üniversitesi Eğitim Bilimleri Enstitüsü, Yaşam Boyu Öğrenme ve Yetişkin Eğitimi Anabilim Dalı, Halk Eğitimi Bölümü Öğretim Üyesi, Ankara, Türkiye. E-posta: muysal@ankara.edu.tr
} 


\section{GíRIŞ}

Dünyanın birçok yerinde olduğu gibi ülkemizde de kadınların erkeklere göre ikinci planda görüldüğü, kötü koşullara maruz kaldığı bilinmektedir. Kadınlar ev içinde ve kamusal yaşamda; eğitim, ücretlendirme, sosyal haklar bağlamında cinsiyetlerinden dolayı olumsuz koşullarla mücadele etmek zorunda kalmaktadır. Bu durum kadın ve erkeklere farklı toplumsal rol ve kalıp yargılarlar yüklenmesiyle yakından ilintilidir.

Toplumsal yaşamda kadın ve erkeklere belirli davranış kalıplarının ve rollerin uygun görülmesi, cinsiyet ve toplumsal cinsiyet kavramları çerçevesinde açıklanır. Kadın ve erkek olmanın biyolojik ayrım noktaları, doğuştan getirilen, öğrenilmemiş özellikleri içeren cinsiyet (sex) terimiyle ifade edilirken; sosyal ve kültürel yönü ise öğrenilmiş, sosyalleşmeyle kazanılmış olan özellikleri içeren toplumsal cinsiyet (gender) terimi ile ifade edilir (Dökmen, 2004:4).Toplumsal cinsiyet, kadın ve erkek arasında sadece biyolojik değil aynı zamanda sosyal ve kültürel değerlerin oluşturduğu farklılıkların bulunduğunu işaret eder.Toplumsal cinsiyetin kazanılması ve cinsiyetler arası farklılıkların oluşması Althusser, Lacan ve Foucault gibi düşünürlerin görüşleri temelinde farklı kuramlarla açıklanmıştır (Unat, 1995:27).

Toplumsal cinsiyetle ilgili literatürde en yaygın kullanılan yaklaşımlardan biri Toplumsallaşma kuramıdır. Buna göre, kadın ve erkeğe atfedilen davranışlar, toplumsal olarak belirlenir Doğduğunda sadece biyolojik bir cinsiyeti olan bireyin, zamanla toplumsal cinsiyeti oluşur (Connell,1998:255), toplum cinsiyetine uygun davranışları yapan bireyi ödüllendirilir göstermeyenleri de cezalandırır. Simon de Beauvoir'ın belirttiği gibi kadın, erkeğe göre, yani norm kabul edilen, geçerli sayılan cinse göre; "eksik","edilgen", "güçsüz","duygusal” ve "yeteneksiz" olarak tanımlanır (Doltaş, 1995:51). Sözü edilen bu nitelikler kadının algılanışını olumsuz etkiler.

Marksist kuramlara göre ise kadın sorunu ekonomik sistemle ilişkilidir. Kadınların ezilmesinin temel belirleyenlerini sınıf ilişkileri, kapitalist sistem veya üretim ilişkileridir. Marksist devrimle birlikte kapitalizmin yıkılacak ve kadının ezilmesi sorununu ortadan kalkacaktır (Connell, 1998: 70). Kurama göre kadınlar, kapitalist sistemde ücretli iş dışında bırakıldıkları ve kapitalist sistemin ücretli işçilerinin yeniden üretilmesi için evde çalışmaları gerektiği için daha fazla ezilmektedirler (Hartmann, 2006:9). Yeniden üretim olarak adlandırılan bu sistemde kadının görevi üretim alanındaki boşlukları doldurmak üzere çocuk doğurmak ve günün sonunda yorgun işçiye hizmet etmek (Connell, 1998:72) olarak görülmektedir. Bu bağlamda Marksist kuramlar kadının ezilmesinden sorumlu tuttukları kapitalist sistemi 
değiştirmeden bu sorunların çözümünün mümkün olamayacağını ortaya koymaktadir.

Bir diğer kuram ise Freud'un psikanalitik kuramı temelinde toplumsal cinsiyetin oluşumunu psikolojik süreçlere dayalı olarak açıklar. Buna göre, erkeklerin küçükken anneye bağımlı oldukları için güçsüz ve zayıf bir dönem yaşanmaları, güçsüzlüklerinden sorumlu tuttukları, başta anneleri olmak üzere bütün kadınları egemenlik altına almak istemelerine neden olur (Doltaş, 1995:55).Erkeklerdeki bu psikolojik süreçler onların kadınlarla ilişkilerine yansır ve bu da kadınların ezilmesine neden olur. Chodorow'a göre ise anneler kendilerine benzeyen, annelik duyguları gelişmiş kız çocuklar yetiştirirken, erkek çocuklarda bu duygular aile tarafından bastırılır.Bu süreçte erkek çocuklara daha çok ev dışı görev ve sorumluluklar verilir. Ev dışı işler toplumsal anlamda ev içindekine göre daha önemli görüldüğünden bu sorumluluğu alan erkeklerin konumu kadına göre yüksek algılanır (Doltaş, 1995: 56).

Post-yapısalc1 kuram ise toplumsal cinsiyetin iletilmesi, yorumlanması ve temsilinde dil üzerinde durarak "kadın" ve "erkek" gibi kategorilerin doğa tarafından değil, kültürel ve toplumsal olarak inşa edildiğini, kültürler ve tarihsel dönemler arasında kayda değer bir değişim gösterdiklerini savunur (Schroeder, 2007: 71). Erkek ve kadın kültürleri arasındaki farklılıkların tarihsel olarak üretildiğini savunan bu yaklaşım, öznellik ve kimliğin toplumsal olarak inşa edildiğini öne sürer.

Toplumsal cinsiyet kuramlarının açıkladığı üzere kadınlar ve erkeklere biçilen roller toplumda cinsiyetçi düşünce, tutum ve davranışların oluşmasına neden olur. Cinsiyetçi yaklaşımların toplumsal alana yayılması ve sürekliliğinin sağlanmasında kitle iletişim araçları önemli bir görev üstlenir. Kitle iletişim araçları bireylerin toplumsallaşmasının, kültürün, bilginin ve toplumsal değerlerin sonraki kuşaklara aktarılmasının temel taşıyıcısı olma; haber verme, kamuoyu oluşturma, siyasal sürece katılma ve eğitim (Geray, 2002:98) gibi olumlu işlevlere sahiptir. Ancak liberal yaklaşımların öngördüğünün aksine kamuoyunu doğru, çok boyutlu, yansız, dengeli, hızlı ve yeterli bir biçimde bilgilendirmek yerine iktisadi, siyasi ve ideolojik olarak güçlülerin iktidarlarını pekiştirici bir biçimde haber aktarımı gerçekleştirir (İnal,1996). Medya, toplumun ne zaman ne konuşup tartışacağını ne ile meşgul olacağını yani gündemi belirleme özelliğine sahip olduğu için (Neumann, 1998:180) toplumda önemli bir güç olarak yer almakta ve buradaki söylemler de siyasal ve ekonomik güce sahip olanların çizgisini yansitmakta, yurttaşlar, tüm olaylara bu grubunun gözüyle bakmak zorunda kalmaktadır.Bu nedenle de kitle iletişim araçları insanları standartlaştırmakta ve otoriteler tarafından kontrol edilmelerini kolaylaştırmaktadır (Ayhan, 2001: 59; Lindeman, 1969: 67). 
Kitle iletişim araçlarında erkek egemen bakış açısının hâkimiyeti gözlenmektedir. $\mathrm{Bu}$ söylem ana hatlarıyla kadını pasif, kolayca el konulabilir, hükmedilebilir, parçalarına ayrılıp çeşitli amaçlar için kullanılabilir seyirlik bir cinsel haz nesnesine dönüştürmektedir (Winship, 1980:217). Kadın, basmakalıp bir şekilde şiddete maruz kalan kadın, zavallı, korunmaya muhtaç kadın, iyi eş, iyi anne, kötü eş, kötü anne, yuva yıkan kadın, tüketen kadın, tükettiren kadın başlıkları altında haber edilmekte ve kadına ev içi roller biçilmekte kamusal alan erkeklere aitmiş gibi yansıtılmaktadır. Kadınların bağımlılığını ve ikincil konumlarını pekiştiren cinsiyetçi ideolojiye ya da ataerkil yaşam tarzına hizmet eden bu söylemler kadınların eve ve aileye ilişkin rollerinin önceliğini vurgulamaktadır (Gürses, 2003:9).Sunulan cinsiyetçi mesajlar da toplumda kadınların algılanma biçimini etkilemekte bu egemen kalıp yargılar, sürekli yeniden üretilerek toplumsal alanda dolaşıma sokulmaktadır.

Kitle iletişim araçlarından biri olan gazetelerde sözü edilen durum köşe yazılarına yansımaktadır. Gazetenin ideolojik yapısı temelinde köşe yazılarında egemen bakış açısı sürekli gündeme getirilmekte, bu durum egemen değer ve inançların köklenmesine neden olmaktadır. Bu problem çerçevesinde çalışmada gazetelerin köşe yazılarında kadının algılanışı, yazarların söylemlerinde cinsiyetçi yaklaşımlar sergileyip sergilemediği, kadın eğitimine yönelik yaklaşımlarının neler olduğunun ve söylem farklılıkları ya da benzerliklerinin neler olduğunun ortaya konulması amaçlanmıştır.

\section{YÖNTEM}

\section{Araştırmanın Modeli}

$\mathrm{Bu}$ çalışma tarama modelinde betimsel bir araştırmadır. Bu çalışmada köçe yazılarında toplumsal cinsiyet ve kadın eğitimine ilişkin söylemler analiz edilmeye çalışıldığından betimsel tarama modeli kullanılmıştır. Çünkü, tarama modeli geçmişte ya da halen var olan bir durumu varolduğu şekliyle betimlemeyi amaçlayan araştırmalara uygun bir araştırma yaklaşımıdır (Karasar, 2008: 77).

\section{Evren ve Örneklem}

Çalışma, ülkemizde yayımlanan Hürriyet, Radikal, Birgün ve Zaman olmak üzere dört ulusal gazete üzerinde yapılmıştır. Çalışma, 01.01.2006 31.12.2006 tarihleri arasında yayımlanan ve yukarıda adı geçen gazetelerin köşe yazıları ile sınırlandırılmıştır 
Tablo 1. Evren ve Örneklem

\begin{tabular}{llcc}
\hline Gazeteler & Evren (\% 100) & Örneklem (\% 10) & Kösse Yazısı (Adet) \\
\hline Hürriyet & 365 & 36 & 623 \\
Radikal & 365 & 36 & 461 \\
Birgün & 365 & 36 & 221 \\
Zaman & 365 & 36 & 315 \\
& & & \\
Toplam & 1460 & 146 & 1620 \\
\hline
\end{tabular}

Tablo 1'de görüldüğü üzere, 146 adet gazete örneklem olarak alınarak buradaki 1620 köşe yazısı analiz edilmiştir.

\section{Veri Toplama Araçları}

$\mathrm{Bu}$ çalışmada verilerin elde edilmesi ve analizi, nitel araştırma

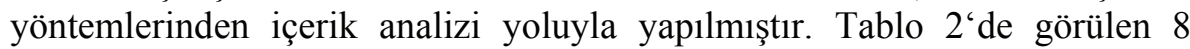
kategoriye göre veriler toplanmıştır. Kategorilerin oluşturulmasında Köşe Yazılarında Toplumsal Cinsiyet ve Kadın Eğitimi Genel Kategori olarak belirlenmiştir. Daha sonra Kamusal Yaşamda Kadın, Kadın ve Şiddet, Medyada Kadın, Din ve Kadın, Geleneklere Dayalı Toplumsal Yaşam, Kadın Eğitimi, Kadın Haklarını Sorgulamaya Yönelik Bilinçlendirme Çalışmaları ve Diğer olarak belirlenen temalar çerçevesine özel kategoriler belirlenmiştir.

\section{Verilerin Analizi}

Veriler Tablo 2'deki kategorilere göre toplandıktan sonra önce sayısal olarak her bir köşe yazısında bu temalara ne kadar değinildiği saptanmıştır. Elde edilen sayılar yüzdelik olarak tablolara yansıtılmıştır. Sonra da köşe yazılarındaki söylemlerin içeriği analiz edilmiştir. 
Tablo 2. Genel ve Özel Kategoriler

Genel Kategori: Köşe Yazlarında Toplumsal Cinsiyet ve Kadın Eğitimi

\begin{tabular}{ll}
\hline & 1.Kamusal Yaşamda Kadın (iş yaşamı, siyaset, ekonomik hayat. \\
Özel & sağlık toplumsal hayat ve, hukuk) \\
Kategoriler: & 2.Kadın ve Şiddet (cinsel şiddet, psikolojik ve fiziksel şiddet, töre \\
cinayeti, fuhuş, kapkaç ve suç) \\
3.Medyada Kadın(Televizyon, gazeteler, dergiler, radio ve internet \\
ortamında kadına yönelik cinsiyetçi eğilimler) \\
4.Din ve Kadın (türban, örtünme, din ve ahlak kuralları İslam'da \\
kadın temaları) \\
5.Geleneklere Dayalı Toplumsal Yaşam (gelenekselroller, kadına \\
yönelik ataerkil bakış, toplumda kadına yönelik kalıp yargılar) \\
6. Kadın Eğitimi (okuma yazma etkinlikleri, anne eğitimi örgün \\
eğitim ve onun dışında kalan her türlü eğitim ) \\
7.Kadın Haklarını Sorgulamaya Yönelik Bilinçlendirme \\
Çalışmaları (kadın hakları için yapıllan eylemler \\
8. Diğer (pozitif ayrımcılık)
\end{tabular}

\section{BULGULAR}

\section{Kamusal Yaşamda Kadın}

Kamusal yaşamda kadın kategorisi, kadının iş yaşamı, siyaset, ekonomik ve toplumsal hayat alanlarında ele alındı $\breve{g}_{1}$ kategoridir. $\mathrm{Bu}$ kategori, araştırma kapsamındaki dört gazeteden, en çok Birgün Gazetesinde; \% 1,8 oranı ile yer bulurken, Hürriyet'te \% 1,1 oranında, Radikal'de \% 0,8 oranında yer almıştır. Diğer üç gazeteye göre kadının kamusal yaşamdaki konumu kategorisinin en az işlendiği gazete, $\%$ 0,6 oranı ile Zaman olmuştur. Kamusal alana ilişkin elde edilen veriler, erkeklerin bu alanda iktidar olarak görüldügünü; kadınların ise daha geri plandaki özel alan olarak görülen ev ile özdeşleştirildiklerini göstermektedir.

Kamusal yaşamda kadın kategorisinde, 'siyasette kadın' teması, Zaman Gazetesinde hiç yer almamış, diğer üç gazetede ise ortak vurgulanan tema olmuştur.Kadının kamusal alanda erkekler gibi var olması gerektiği mesajı Hürriyet ve Radikal Gazetesinin ortak yönünü oluşturmuştur. Örneğin Hürriyet Gazetesi yazarlarından, Mehmet Y.Yılmaz, 30 Haziran tarihli köşe yazısında, kızların erkeklerden daha çok çalışmak zorunda olmasını, her iki cinse aynı olanakların tanınmamasına bağlayarak kızların buna mecbur kaldığının altını çizmiştir. Radikal Gazetesinde Türker Aklan Japonya Büyükelçisi Solmaz Ünaydın'ın cinsiyetinden dolayı yıllarca büyükelçi yapılmadığı yönündeki açıklamalarını tartışmış, aynı gazeteden Metin Ercan ise, kadınların düşük ücretli, az beceri isteyen, kısmi zamanlı, geçici ve kayıt dışı işlerde istihdam edildiğini ifade etmiştir. 
Birgün Gazetesinde toplumsal yaşamda, kadınların erkeklerden daha çok bedel ödemesi gerektiği ve toplumu ayakta tuttuğu düşüncesi üzerinde sıklıkla durulmuştur.Örneğin Uğur Cilasun, tüm dünyada, savaşın, yokluğun, sıkıntının bedelini kadınların ödediğini, dünyanın her bölgesinde kadının yıkıntılar arasında her şeyi yeniden yaratmak zorunda kaldığını; Ozan Ceyhun ise insan hakları bağlamında ortaya konulan hakların, ayrım yapılmadan kadınlara da tanınmasının önemli olduğunu vurgulamıştır. Aynı gazete yazarlarından Serdar Şen ise kadın ve erkeklerin eşit olması gerektiğine dair söylemin sistem içinde olması gerektiği fikrini eleştirerek, kadınların böyle bir sistemde eşitlik talebinin çok yerinde olmadığını ifade ederek konuyu politik zeminde tartışmıştır.

Zaman Gazetesinde siyasi yaşamda, iş yaşamında kadından söz edilmemiş, kadın özel alana uygun görülmüştür. İslami geleneklerde mecbur kalmadıkça kadının kamusal alanda bulunması, çalışması hoş karşılanmamaktadır ancak, kadın eğitim aldıysa ve çalışmak durumundaysa İslami yaşam tarzına uygun olmak koşuluyla, kamusal yaşamda bulunmasına izin verilmiştir. Gazetede kamusal yaşamda kadın teması, Şahin Alpay'ın köşesinde yer bulmuş o da cinsler arası eşitliğin, kadına tanınan hakların, diğer Müslüman ülkelerden daha ilerde olmasına rağmen, bu hakların uygulanmasında her türlü bağnazlıklar ve törelerin büyük engel oluşturduğunu ifade etmiştir.

\section{Kadın ve Şiddet}

Araştırma sonucundaki verilere göre kadın ve şiddet kategorisi Radikal'de \% 1,5 Birgün Gazetesinde ise \% 1,3 oranında yer bulmuştur. Hürriyette bu oran \%1,2 olurken; Zaman'da konuya ait herhangi bir bulguya rastlanmaması dikkat çekici bulunmuştur.

Hürriyet'te köşe yazarları kadın ve şiddet teması konusunda namus ve töre cinayetleri üzerinde odaklanmıştır.Burada kadının şiddet nesnesi olması konusu; genel olarak doğuya özgü bir mesele, geleneksel bir sorun olarak yansıtılmış; ancak ataerkil toplum yapısının, kadına yönelik şiddetin temel kaynağı olduğu, açıkça belirtilmemiştir.Hürriyette namus cinayetleri dışında fiziksel şiddet temasına gazetenin kadın yazarlarının köşelerinde yer verildiği görülmüştür.Şiddete maruz kalma nedenleri zaman zaman ön plana çıkarılarak şiddet haklılaştırılmakta, şiddet eyleminin aktörü erkek ve erkeğin içinde yetiştiği toplumun erkek egemen değerleri sorgulanmamaktadır (Binark ve Gencel - Bek, 2000: 10). Hürriyet Gazetesi nin söylemleri bu duruma örnek teşkil etmektedir. Yazarlar genel olarak şiddetten, bu durumun nasıl olduğundan ve nedenlerinden söz etmişler fakat bu durumun asıl sebebi olan toplumsal yapılanmayı ve erkek egemen 
sistemin sürekli yeniden üretilip topluma sunulmasını ve bu durumun sorgulanmasını ortaya koymamışlardır.

Radikal Gazetesinde de ağırlıklı olarak; namus, töre cinayetleri üzerinde durulmuştur; Hürriyet Gazetesinin söylemlerine paralel olarak suçun bastırıldığını, örtbas edildiğini ve yerel makamların bile bu işe engel olmada çekimser davrandığı ifade edilmiştir.Aynı gazeteden Türker Aklan da töre cinayetleri ve şiddet olgularının dünyada özellikle Müslüman ülkelerde yaygın olduğunu belirterek, Müslüman toplumların yaklaşımlarını tartışmıştır.

Birgün Gazetesinde de diğer iki gazetede olduğu gibi namus, töre cinayetleri, dayak ve psikolojik şiddet olayları, kadın - erkek eşitsizliği üzerinden tartışılmıştır.Örneğin Serdar Şen konuyla ilgili olarak toplumsal yapının; kadınların erkeklerle eşit koşullarda yetiştirilmesini engellediğini, toplumun kadın ve erkeklere farklı roller biçtiğini ve bunun dışına çıkmaya çalışan kadının şiddetle karşılaştığını ifade etmiştir.

\section{Medyada Kadın}

Medyada kadın kategorisi, kadınların gazete, dergi, kitap, televizyon, radyo, internet gibi iletişim araçlarında var olma biçimlerinin köşe yazarlarının bakış açısı doğrultusunda değerlendirildiği kategoridir. Değerlendirmeye alınan yazılar içerisinde, medyaya yönelik eleştirilerin büyük bölümünün Zaman Gazetesinde olduğu görülmüş̧ür.Zaman Gazetesi $\%$ 1,5 oranında konuya değinirken, Birgün Gazetesi \% 0, 9 oranında, Radikalde \% 0, 8 oranında, Hürriyet Gazetesi ise \% 0,3 oranında konuyu ele almıştır.

Zamanda, gazetenin İslami çizgisi ve dünya görüşü ile uyumlu eleştiriler getirmiş olduğu görülmüştür.Gazetede türban takan kadının medyada yansıtılması eleştirilmiştir. Örneğin Sami Uslu, başını kapatan, İslami yaşam tarzına uygun davranan kadının medyada konu yapılmasını eleştirmiş, ancak medyanın kadını konu yapmasını; toplumsal cinsiyet açısından değil kadının İslami kimliğini yaşaması nedeniyle eleştirmiştir. Öte yandan Zaman Gazetesinde 'kadının medyada cinsellik nesnesi olarak kullanılması' olgusunun diğer üç gazeteye oranla çok daha fazla ele alındığı tespit edilmiştir.Örneğin Günseli Özen Ocakoğlu, televizyondaki birçok reklâmın cinsel önermeler üzerine kurulduğunu vurgulamıştır. Özellikle yiyecek ve tatlı reklamlarında, cinsel bir obje olarak sunulan kadın ürünün satışını artırmak için kullanılan bir araç olarak kullanıldı̆̆ına değinmiş, Nedim Hazar futbol karşılaşmalarında, kadınların seyirlik nesne ya da süs nesnesi olarak izlenme oranını artırmak amacıyla yayınlarda kullanıldığına 
değinmiş ve erkeklerin ilgi alanına giren program aralarında izlenme oranını artırmak için kadının; cinsel bir obje olarak sunulmasına karşı çıkmıştır.

Zamanda kitle iletişim araçlarının mesajlarının insanları şekillendirmeye çalıştığ1 yönünde söylemlerle sıklıkla karşılaşılmıştır. Örneğin Elif Şafak kitle iletişim araçlarından yayılan cinsiyetçi kalıplar ve kadınlara yönelik olarak geleneksel yaşama ait dayatmaları, nasihatleri eleştirilmiş; medyada iyi kadın - kötü kadın olarak yaratılan ikilemin, yeni yetişen kuşaklar için örnek olarak gösterilmesini yargılamıştır.

İncelenen dört gazetede de dikkat çeken ortak nokta; medyanın toplumsallaştırma ve eğitim işlevlerine sahip olduğu yönündeki vurgudur. Örneğin Hürriyet'te Yalçın Bayer'in köşesinde, bir televizyon dizisinde yer alan, kadına yönelik olumsuz tutumların; erkek izleyicilere örnek olma tehlikesi üzerinden ifade edilmiş, Zaman'da ise Ahmet Selim, özellikle televizyon dizilerinde kadınların erkeksi davranışlara özendirdiğini, insanları eğitme işlevi olan medyanın baş sorumlu olduğunu vurgulamıştır.

\section{Din ve Kadın}

Din ve Kadın kategorisi, \% 3, 4 oranıyla en çok Zaman Gazetesinde yer almıştır. Bunu Hürriyet Gazetesi, \% 1, 7 oranı ile takip ederken, Radikal ve Birgün Gazeteleri \% 1, 3 oranı ile bu kategoriye eşit yer ayırmıştır. Din ve kadın kategorisinde; kadınların türban takması ve türban yasağı, haremlikselamlık uygulamalara maruz kalmaları, yaşamlarını dini kurallara göre düzenlemeleri konusundaki yaklaşımlar genel olarak yazarların ele aldığı sorunlar olmuştur.

Türban ve örtünme tüm gazetelerde köşe yazarlarının ağırlıklı olarak değindikleri konu olmuştur. İslamcılar, Kuran'a göre, başı örtmenin gerekliliğini savunurken, Kemalistler bunun Laikliği tehlikeye attığı fikri üzerinde birleşmiştir. Örneğin Hürriyet'te, Mehmet Ali Birand eğer türban takmak bir özgürlük olarak kabul edilecekse, türban takamamanın da başkaları için özgürlük olabileceğini ve türbanın; erkeklerin günah işlememek için kadını kontrol altında tutmanın, bir yolu olduğunu ifade etmiş, Birgün'den Günersel de bu fikri destekleyerek kadınları; başını örtme gibi yaptırımlara tabi tutmanın toplumsal cinsiyet eşitliğine uygun olmadığın, birtakım yaptırımların da erkelere neden uygulanmadığın sorgulamıştır.

Birgün'de türbanın cinsiyet eşitsizliği olarak algılanmasının aksine giysinin, ahlaki bir işleve, kadının namusunun korunması işlevine sahip olduğu (Göle, 2004:126) düşüncesi temelinde Zaman Gazetesinde türban özgürlüğü vurgulanmıştır.Örneğin Zaman yazarlarından Nedim Hazar, 21 Ocak tarihli yazısında, türban yasağın her biçiminin denendiğini ve 
neredeyse, oksijensiz bırakılmaya kadar gideceği yönünde kararlar alınacağını ironik bir dille eleştirmiş, Nihal B.Karaca ise; kadının başı açık olarak namaz kılmasının ve erkekler gibi namazda ellerini bağlamaları gibi İslami geleneklerde olmayan durumları kınamıştır.

Zamanda dikkat çeken nokta; çok eşlilik, kadınların şiddet görmesi, kadının sosyal ve ekonomik hakları gibi olguların Zaman gazetesinde yer almaması, 'kadının' sadece türban sorunu ile hatırlanmış olması bu konu yazarların temel gündem konusu haline gelmiş kadının başka sorunları görmezlikten gelinmiş olmasıdır. Sözü edilen sorunlar üzerinde diğer gazetelerin ise sıklıkla durduğu gözlenmiştir.Örneğin Radikalde Türker Alkan, değişen dünya düzeninin İslam'da kadın olgusunu etkilediğini vurgulayarak Müslüman ülkelerde kadınların yaşadığı zorlukları ortaya koyduğu yazısında, kadınların üretimden dışlandığını, siyasal ve toplumsal sorunlarla karşılaşmak zorunda kaldıklarını söylemiştir. Suudi Arabistan'da kadınların kalabalık nedeniyle arka planda ibadet etmesi yönünde verilen kararı cinsiyetçi bir karar olarak görmüş̧ür. Laik yaşam tarzına uygun olmayan olayların ve yaşantıların Radikalde olduğu gibi Hürriyet'te eleştirildiği tespit edilmiştir.

Toplumsal yaşamda, özellikle Cumhuriyet'in kadınlara tanıdığı temel hakları yok sayan uygulamalar, kadınların ikinci planda olmasını dini geleneklerle açıklayan görüşler, Hürriyette en çok dile getirilen noktalar olmuştur. Örneğin, Yalçın Doğan, kadınlar ve erkeklerin; haremlik selamlık olarak iki ayrı mekânda tutulduğu bir düğünü, bugünün İstanbul'unda gerçekleştiğini eleştirmiştir.

Dine dayalı toplumsal kuralların kadınlar üzerinde baskı oluşturduğu fikri Zaman hariç üç gazetede de yer almıştır. Örneğin Hürriyette Emin Çölaşan, kadınlar üzerindeki baskının esas olarak erkeklerin yaşam alanını genişletmek ve dini bakımdan sorumlu görülmemek için yapıldığını vurgulanmış; Bekir Coşkun ise kadınlar ve erkeklerin yaşam alanlarını ayrıma girişimini eşleştirmiştir. Coşkun, laiklik ilkesine aykırı olduğunu ifade ettiği yazısında kadınların yaşamlarını özgürce şekillendirememelerinin; erkeklerin kendi çıkarları için oluşturulan bir düzen nedeniyle gerçekleştiğini ortaya koymuş, Radikalde Yılmaz, ise park gibi kamuya açı mekânların kadın ve erkek bölümü olarak ikiye bölünmesinin, kadının cinsel kimliğine yapılan vurgu olduğunu ve yerel yönetimlerin cinsiyetçi bakışını yansıttığını eleştirmiş;; aynı gazeteden Türker Alkan, kadının, dini gerekçelerle erkeğe tabi olmasını eleştirmiştir. Bu yaklaşımın aksine Zaman Gazetesinde Hekimoğlu İsmail ise, İslami yaşam biçiminde kadının evlilikte başarısını, dinin emirlerine uygun yaşamasında görmüş̧ür. 


\section{Geleneklere Dayalı Toplumsal Yaşam}

Toplumsal yaşamda, kadın ve erkeklere yüklenen alışılagelmiş tutumlar ve davranış kalıpları vardır. Örneğin, ülkemizde hâkim olan geleneksel anlayışta, kadının yeri kocasının yanıdır ve kadının temel sorumluluğu, kocasının ihtiyaçlarını karşılayıp bakımını sağlamak ve çocuk yetiştirmekle belirlenirken, erkelerin konumu, çalışıp para kazanması ve geleneksel rollerini sürdürmesi olarak görülmektedir. Geleneksel anlayışta, kadının temel iki toplumsal rolü vardır: 'eş' ve 'annelik' rolleri. Bu roller cinsiyete göre belirlenirken, kadının toplumsal yaşamın diğer alanlarında var olma çabası görmezlikten gelinmekte ya da olumlu karşılanmamaktadır. Bu doğrultuda incelenen gazetelerden Zaman Gazetesinin \% 1, 9 oranında, Hürriyet'in ise, \% 1, 6 oranında bu tema üzerinde durduğu, tespit edilmiştir. Konu, Birgün'de \% 0, 9 ve Radikal'de \% 0, 8 oranında ele alınmıştır.

Zaman Gazetesinde, kadının cinsiyetine bağlı olarak ona yüklenen annelik ve eşlik rollerine vurgu yapılarak geleneksel kadın imajını pekiştirecek mesajlar verildiği görülmüştür.Örneğin Hekimoğlu İsmail, kadının aile içindeki konumunu vurgulayarak bu konumun getirdiği yükümlülükleri, fazilet olarak adlandırmış, Nihal B. Karaca da aileyi; temel değerlerin korunduğu, kadının temel yaşam alanı olarak yansıtmıştır. Zamanda giyim kuşam ve davranışla konusunda kadınların dikkat etmesi gereken noktalara vurgu yapılmıştır. Örneğin A. Turan Aklan, özellikle muhafazakâr kesim kadınlarının; giyim-kuşamlarındaki serbestliği, davranışlarındaki rahatlığı, kınanarak temelde bu tür davranışların kadının, iffetine zarar verdiği mesajını verilmiştir. Alafrangalaşmak olarak adlandırdığı, batılı giyim tarzı ve davranış modelleri, İslami yaşam tarzı için bir tehlike unsuru olarak görülmektedir. Dolayısıyla kadınların; geleneksel İslam değerlerine uygun davranmaları ve yaşamaları gerektiği mesajı verilmektedir. İslami yaşam tarzında kadınlar iffetin taşıyıcıları ve çocukların sosyalleştirilmesinde kilit temsilciler olarak övülmektedirler. Aile değerleri ve bu değerlerin yayılmasında kadınların ana rolü kabul edilmekte ve söylemlerinde bu konuya özel bir önem verilmektedir (Kazemi, 2004: 255).

Cinsiyet rolleri Zamanda net olarak çizilmiştir. Bunun dışına çıkanların, yazarlar tarafından olumsuz bir biçimde eleştirildiği görülmüştür. Örneğin Ali Bulaç, 'kadın gibi ağlamak' sözünü köşe yazısında kullanmış ve bu şekilde davranan erkekleri yermiştir. Geleneksel değerler, insanlara, öz olarak algılanan cinsiyetlerine ilişkin roller biçmektedir. Bu kavrayışa göre kadınlar özlerine uygun bir biçimde davranmalı; neredeyse salt cinsiyetlerine ait özelliklerini yaşama alanına geçirmek üzere ne yapılması gerekiyorsa, 
onu yerine getirmelidirler(Çotuksöken, 2006:1).Bu noktada, Zaman'da muhafazakâr ve geleneksel mesajlar verilmiştir.

Zaman Gazetesindeki 'geleneksel kadın' imajını pekiştirici önermelerle bazı köşe yazılarında da karşılaşılmıştır. Örneğin Hürriyet Gazetesinde Yalçın Doğan, iyi araba kullanmanın, erkeklere has bir özellik olduğunu kadınların, erkeklerden daha kötü araba kullandığını, bir araştırma bulgusunu referans alarak aktarırken, 'bilime kızılmaz ki’ sözü ile bunu temellendirmeye çalışmıştır.

Zaman dışındaki diğer gazetelerde az da olsa kadının geleneksel rolleri konu edilmiştir.Örneğin Hürriyette Bekir Coşkun; kadının toplumsal yaşamda kadın emeğinin görünmezliğini ortaya koymuş, birçok iş ve vasfın; kadının temel görevleri olarak kanıksandığını ve bunun da doğal bir durum olarak görüldüğünü belirterek aslında kadının omuzlarına yüklenen bu kadar yükün toplumsal cinsiyet eşitliği açısından büyük bir sorun olduğunu ifade etmiştir. Radikalde Funda Özkan da ülkemizde hâkim olan kadına bakış açısının cinsiyetçi önermeler içerdiğini ortaya koymuş, kadınların geleneksel anlamda ev içi sorumlulukların tümünü yüklendiği, her yönden erkeklere tabi olduğu, ev dişında bir işte çalışıyorsa namusuyla işini yapması gerektiği anlayışını dile getirerek bu durumu eleştirmiştir.Birgün Gazetesinde da kadınlar için çizilen bu tablo üzerinde az da olsa durulmuş, örneğin Yaşar Seyman Asmin, kadını sadece anne - eş rollerini oynayan bireye indirgeyen bu geleneksel bakış açısını eleştirmiştir.

\section{Kadın Eğitimi}

Kadın eğitimi kategorisinde, köşe yazılarında, kadınların; örgün eğitime ve bunun dışında kalan her türlü eğitime katılmasına ilişkin köşe yazarlarının görüşleri değerlendirilmiştir.Kadın Eğitimi kategorisi, Zaman Gazetesinde, \% 1, 9 oranında, Hürriyet Gazetesinde, \% 1, 2 oranında, Birgün Gazetesinde \% 1, 3 ve Radikal Gazetesinde de \% 0, 4 oranında yer almıştır.

Hürriyet, Radikal ve Birgün eğitim; kadınların örgün eğitime katılmalarındaki sıkıntılar üzerinden işlenmiştir. Ağırlıklı olarak okullaşmadan, ilköğretim ve ortaöğretime ilişkin sayısal verilerden söz edilmiş ve kadınların eğitimsizliğinin getirdiği sorunlar kısmen ortaya konmuştur. Örneğin Hürriyette Cüneyt Ülsever, eğitimde cinsiyet eşitsizliğine vurgu yapmış, ilköğretim düzeyinde okullaşmanın giderek artmasına rağmen, ortaöğretimde ve kızların eğitim olanaklarından faydalanma oranında aynı gelişmenin görülemediğini vurgulamıştır. Şükrü Küçükşahin ise, kadınların eğitimsizliği ile şiddet görmeleri arasında bağlantı kurmuş, olumsuz muamele görmekten dolayı Ka - Mer adlı kadın sığınma evine başvuran kadınların çoğunluğunun eğitimsiz olduğunu 
belirtmiştir. Aynı gazeteden Gila Benmayor da kadının güçlenmesinin, bilinçlenmesinin anahtarının eğitimde olduğunu ifade etmiştir.

Radikalde de Hürriyettekine paralel olarak eğitimde cinsiyetçilik olduğu, kadının eğitim olanaklarından yeterince yararlanamadığı ifade edilmiştir. Örneğin Metin Ercan kadınların, erkeklere göre eğitim olanaklarından daha az faydalandıklarını ve bu yüzden kadınların düşük statülü işler yapmak zorunda kaldıklarını belirtilmiştir. Ercan'a göre, eğitimde cinsiyetçilik; toplumsal olarak kadınlara yüklenen roller nedeniyle ve aile yapısının etkisiyle gerçekleşirken, uygun eğitim olanaklarına sahip kadınlar erkeklerden daha başarılı olabilmektedirler. Radikal'de Mehmet Y. Yılmaz ise cinsiyetçi yaklaşımların Müslüman toplumlarda görüldüğünü ortaya koymuş, eğitim ve iş olanaklarından yararlanma fırsatı verilmemesi nedeniyle, kadınların erkeklere göre geri planda kaldıklarını ifade etmiştir.Nur Çintay ise, kadının eğitimli olmasının iyi çocuk yetiştirmede etkisini ortaya koymuştur.

Eğitim sayesinde, cinslere ilişkin toplumdaki hâkim anlayış, kuşaktan kuşağa aktarılır, dolaşıma sokulur anlayışı Birgün Gazetesinde Ozan Ceyhun'un 21 Nisan tarihli köşe yazısına yansımıştır. Ceyhun, verdiği örnekle; toplumda hâkim olan cinsiyetçi kalıpların eğitim yoluyla aktarıldığını ve kadına bilinçli olarak bu şekilde davranıldığını ortaya koymuştur.

Zaman Gazetesinde dikkati çeken nokta ise diğer üç gazeteden farklı olarak, kadının annelik statüsünü vurgulanması ve annelik eğitimi üzerinde sıklıkla durulması olmuştur. Kadınların eş olarak nasıl davranması gerektiği, iyi bir annenin neler yapması gerektiği, ailenin devamı için kadına düşen görevlerin neler olduğu konularında İslam ahlakı ve yaşam kuralları temelinde verilen mesajlar Zaman Gazetesinin temel önermeleri olmuştur. Örneğin Fatih Uraz, çocukların sorumluluklarını annelere hatırlatan bir sesleniş yapmış, Hekimoğlu İsmail ise 'kadın iyi bir eş nasıl olur' sorusunun yanıtını, İslam ahlakına uygun erkek egemen bakış açısı çerçevesinde yanıtlanarak kadının yüklenmesi gereken bir dizi sorumluluk bulunduğu ifade edilmiştir. Ahmed Şahin ise, İslam'ın emirlerini, anne-baba ve evlat arasındaki ilişkileri düzenlemek bakımından temel kural olarak uygulamak gerektiğini belirtmiş, bir başka yazısında ise kadının doğum yapma, bebeği dünyaya getirip getirmeme durumunu da İslami yaşam tarzına uygun bir temelde olması gerektiğini ifade etmiştir. Bununla birlikte kadının sadece kendi yaşamını değil, rollerini de dini kurallar çerçevesinde şekillendirilmesi gerekliliği, Zaman'da kadın eğitimi bağlamında sıç̧a karşılaşılan bir mesaj olmuştur. Örneğin A.Turan Alkan, kadınların annelik rollerini oynarken İslami kurallara uygun davranmaları gerektiğini söylemiş, kadınlara; dış görünüşte benzemenin inançlarda da benzeme anlamına geleceği mesajı 
verilerek, batılı kadına benzemenin ölçütü olarak görülen modayı takip etme, makyaj yapma, gibi davranışlardan kaçınmaları öğütlenmiştir.

\section{Kadını Bilinçlendirmeye Yönelik Eylemler}

Kadın haklarını sorgulamaya ve kadını bilinçlendirmeye yönelik eylemler, çalışmalar ve gösterilerin değerlendirildiği bu kategoride, köşe yazarlarının verdikleri mesajlar toplumsal cinsiyet bağlamında incelenmiştir. Bu kategori, Birgün'de \% 0, 9 oranında, Hürriyet'te \% 0, 4 ve Radikal'de \% 0,2 oranında ele alınan bu kategori, Zaman'da hiç yer almamıştır.

Kadını bilinçlendirmeye yönelik eylemler, çalışmalar ve gösterilere ilişkin mesajların; incelenen gazetelerin hiçbirinde yeterli olarak verilmediği görülmüştür.Hürriyet'te yazarlar, doğrudan kadınlara seslenerek bu temaya değinmiştir. Örneğin Mehmet Ali Birand, kadınların kendi haklarını sorgulamak bakımından artık harekete geçmesi gerektiğini, kadının; ev içinde erkeğe göre daha çok söz sahibi olduğunu belirterek bu konumunu ev dışında da kullanması gerektiğini ifade etmiş, Ahmet Hakan ise, bu tür bir çağrıyı bu kez türbanlı kızlar için yapmış, 'Türbanlı kızlara içten bir sesleniş’ başlıklı köşe yazısını, türban yasağına karşı durmaları için kızları uyarmak ve harekete geçmelerini sağlamak için yazmıştır. Hakan, yasağın; bunun muhatabı olanlar ses çıkarmadıkça, yani kadınlar, kızlar bilinçlenmedikçe devam edeceğini ortaya koymaya çalışmıştır.Bu mesajların dışında çok az da olsa bazı yazarlar farklı temalara da dikkat çekmeye çalışmıştır.Örneğin, Doğan Hızlan Bahçeşehir Üniversitesinde gerçekleştirilen şiddet konulu atölye çalışmasını konu ettiği yazısında, bu toplantıya katılarak insanların aile içi eşitliği konusunda bilgilenmesi için çağrı yapmıştır.

Hürriyette olduğu gibi Birgün Gazetesinde de; kadınların kendi haklarını koruma noktasında birer özne olması gerektiği, bu temanın ana mesajı olmuştur. Örneğin Birgün Gazetesinde Yaşar Seyman Asmin; kadın örgütlerine, kadınları ve özellikle anneleri, harekete geçirmek, bilinçlendirmek için çağrı yapmıştır.

Zaman Gazetesinde, konuya ilişkin herhangi bir bulguya rastlanmazken Radikalde kadın eğitimi için düzenlenen kampanyalar üzerinden kadının bilinçlenmesinin sağlanacağ eğitim hakkını hayata geçirmek için yürütülen kampanyadan söz eden Radikal yazarı Metin Ercan; eğitim yoluyla, kadının bilinçlendirileceğini ve bunun için oluşturulan kampanya ve projelerin buna katkısı olacağını ifade etmiştir. 


\section{Diğer (Pozitif Ayrımcılık)}

Köşe yazıları içinde, hiçbir kategoriye yerleştirilemeyen temalar, 'diğer' olarak kodlanan kategoride incelenmiştir.Bu kategoriye alınabilecek tek konu pozitif ayrımcılık olarak belirlenmiştir.Pozitif ayrımcılık, belli özelliklerinden dolayı toplumsal alanda eşitsizlik yaşayan insanların karşılaştığı bu durumu telafi etmek amacıyla onlara olumlu ayrımcılık yapılması olarak görülmektedir. Konuya ilişkin veri, sadece Radikal'de \% 0,4 oranında yer bulmuş, diğer üç gazetede de bulunamamıştır.Radikalde siyasi yaşamda kadınlar için pozitif ayrımcılık yapılabileceği ifade edilmiştir.

\section{TARTIŞMA VE SONUÇ}

Köşe yazılarının toplumsal cinsiyet ve kadın eğitimi bakımından değerlendirildiği bu çalışmada göze çarpan temel bulgulardan biri, İslamcıLaik ayrımı çerçevesinde beliren bir kutuplaşma olmuştur. Kutuplardan birini Zaman gazetesi oluştururken; Hürriyet, Radikal ve Birgün Gazeteleri ise diğer kutupta yer almıştır. Zaman gazetesinde İslami ideoloji çerçevesinde mesajlar verildiği ve kadınla ilgili her türlü olgunun algılanışının dini çerçevede olduğu saptanmıştır. Diğer üç gazetede ise kadın sorunu laik bir bakış açısı doğrultusunda algılanmış ve dini yaklaşımların, kadının kimi hak ve özgürlüklerine engel teşkil ettiği ifade edilmiştir.

Araştırmadaki diğer bir çarpıcı bulgu ise, 1 lımlı bir çizgide duran gazetelerle, daha radikal söylemleri olan gazeteler arasında söylem benzerliğinin olduğunun tespit edilmesidir.Buna göre toplumun genelde liberal, laik ve muhafazakâr olmayan kesimine hitap eden Hürriyet ve Radikalde diğer iki gazeteye oranla daha ılımlı yaklaşımlar ve söylemler kullanıldığ 1 tespit edilmiştir. Zaman ve Birgün Gazetelerinin ise, politik olarak farklı çizgide bulunsalar da diğer iki gazeteye oranla daha radikal ve uç söylemler kullandığı tespit edilmiştir.

Köşe yazılarında kadının nasıl görüldüğüne ilişkin farklı yaklaşımlarla karşılaşılmıştır. Zamanda dinine bağlı, geleneksel kadın, diğer üç gazetede ise modern laik Türk kadını portresi çizilmiştir. Hürriyet Gazetesinde; kentli, modern, iyi eğitim görmüş, hem anne eş rollerini yerine getiren hem de çalışan kadın profili ortaya konmuş, görece cinsiyet eşitliğini destekler yorumlarla karşılaşılmış fakat bu durum, kadının ev içi geleneksel rollerini düzenli sürdürmesi noktasında kabul edilebilir bir durum olarak görülmüştür. Radikal Gazetesinde de Laik, Atatürkçü ve modern kadın idealize edilmiş ve eğitimli, çalışan ama aynı zamanda ev içi sorumlulukları olan kadın profili yansıtılmıştır. Birgün'de modern, laik, eğitimli ve meslek sahibi olan, 
sorgulayan, düşünen, yaşamını şekillendirebilecek kapasiteye sahip olan kadın profili sergilenmiştir. Zaman Gazetesinde ise dinine, evine, ailesine bağlı, namuslu Müslüman kadın figürü, idealize edilmiştir. Kadınının temel yeri evi ve kocasının yanı olarak görülmüş, temel görevi annelik ve eşlik rolleri çerçevesinde tanımlanmıştır.Zamanda, kadın geleneksel çerçevede algılamıştır. Kadın; aile içi ilişkilerde özellikle kocaları ile ilişkilerinde, temel sorumluluk sahibi olan kişi olarak görülmüş, düzeltilmesi gereken problem kendilerinde varsayılarak öğütler verilmiş, kocanın iyi bir aile kurmada yapması gerekenler üzerinde durulmamıştır. Dolayısıyla kadın genel olarak toplumun temel lokomotifi olarak görülen aile kurumunun temel taşı olarak yansıtılmış, kadına düşen sorumlulukları sabırla ve inançla yerine getirmesi gerektiği sık sık tekrarlanmıştır. Bunun yanı sıra kadına, batılı modern kadına benzemenin sakıncaları anlatılmış giyim kuşam, tavır ve hareketlerde dişiliğini asla ön plana çıkarılmaması gerektiği, ifade edilmiştir.

Kadın eğitimi; Hürriyet, Radikal ve Birgün Gazetelerinde genel olarak okullaşma, örgün eğitime katılma üzerinden değerlendirilmiştir. Hürriyet'te kadın eğitimi kadınların örgün eğitim olanaklarından yararlanmaları bağlamında algılanmış ve yazarlar genel olarak kadının ilk ve ortaöğretime katılma oranının yetersizliğini vurgulamışlardır. Gazetede kadınların güçlenmesinin anahtarını eğitimde olduğu yönünde mesajlar verildiği tespit edilmiş ve bunun dışında az da olsa anne eğitimine yönelik mesajlarla karşılaşılmış, bu mesajların da çoğunlukla kadın köşe yazarları tarafından verildiği görülmüştür. Radikal Gazetesinde, Hürriyettekine paralel olarak kadın eğitiminin algılanışı örgün eğitime katılma üzerinden olmuştur.Radikalde kadınların erkeklere oranla eğitim olanaklarından daha az faydalandıkları ortaya konulmuş ve eğitimde cinsiyetçilik olduğu belirtilmiştir.Eğitimle paralel olarak kadınların daha düşük statülü işlerde çalışmak zorunda kaldıkları vurgulanmıştır. Birgün'de ise kadın eğitimine yönelik mesajların oldukça az olduğu ve kadın eğitimi konusun örgün eğitimle ilişkilendirildiği tespit edilmiştir. Zaman'da ise kadınların özellikle kamusal mekânda nasıl davranması gerektiğine ilişkin bilgiler verilmesi kadın eğitimine yönelik mesajlar olarak değerlendirilmiştir. Zaman'da 'kadın eğitiminin' anne ve eş rolleri çerçevesinde algılandığ 1 saptanmıştır. Kadının temel rolü annelik ve eşlik olarak görüldüğünden, kadın eğitimi çerçevesinde verilen mesajlar da iyi anne ve iyi eş olmaya yönelik dini temelli öğütler olmuştur. Buna uygun olarak da yazarların verdiği mesajlar, İslam ahlakı ve yaşam tarzına uygun olarak 'gerekeni yapın gerisini Allah'a bırakın' yönünde kadını itaatkâr, uyumlu ve sorumluluk sahibi olmaya yönelten mesajlar olmuştur. 
Şiddet konusunda Hürriyet ve Radikal töre ve namus cinayetlerine odaklanmıştır.Hürriyet yazarları genel olarak bu sorunun toplumsal bir yara olduğu ve 'gelenek-görenek' çerçevesinde dokunulmazlıklar taşıdığı fikri üzerinde birleşmiştir.Hürriyet'te kadınların maruz kaldıkları diğer şiddet türleri, kapkaç kurbanı olma, psikolojik şiddet, cinsel şiddet, ekonomik şiddet, baskı, fiziksel şiddet, fuhuşa zorlama gibi temalara hemen hemen hiç yer verilmemiştir.Burada kadın yazarların töre cinayeti dışındaki diğer şiddetlerden söz etmesi erkek yazarların olayı toplumsal boyutu ile değerlendirmiş olmaları dikkat çeken bir nokta olmuştur. Şiddet konusunda Birgün'de toplumsal yapı sorgulanmış, erkek ve kadına farklı roller biçtiği söylenmiş sistem eleştirilmiş, Zaman Gazetesinde ise şiddet konusunda hiç bulguya rastlanmaması dikkat çekici bir durum olarak görülmüştür.

Kadının kamusal yaşamdaki konumuna ilişkin Hürriyete liberal bakış açısı çerçevesinde özgürlükçü bir söylem kullanmış olduğu ve dini yaklaşımların toplumsal cinsiyet eşitliğini engellediği yönünde görüşler bildirildiği tespit edilmiştir. Gazetede 'kadın- erkek eşitliği' fikri modern Türk toplumu olmak için gereken bir nitelik olarak gösterilmiştir. Kadınların ezilmesi, ikinci planda görülmesi ve birçok haktan mahrum birakılması yazarlar tarafından tasvir edilmiştir ancak bu durumu yaratan nedenler irdelenmemiş, bu eşitsizliği üreten sistemin ne ile beslendiği ortaya konulmamıştır.Kadınların toplumsal rollerinin dönüştürülmesine; ancak biçimsel, yüzeysel bir noktadan bakıldığı görülmüştür. Radikal Gazetesinde ise, Hürriyet'te olduğu gibi, kadının kamusal alandan ev içine kadar her yerde eşit ve özgür olması gerektiği belirtilmiştir. Cinslerin eşitliği söylemi sık sık tekrarlanmış, özellikle, kamusal alanda kadın-erkek ayrımı yapılması yönündeki uygulamalar eleştirilmiştir.

Birgün Gazetesi ise, sosyalist - sol çizgide tanımlayabileceğimiz bir gazete olmak bakımından özgürlükçü ve eşitlikçi mesajlar veren, kadın erkek eşitliği fikrini sık sık ortaya koyan bir gazetedir. Bu bakımdan burada doğrudan ya da dolaylı olarak cinsiyetçi önermelere rastlanmamıştır.Bu yönü ile Birgün Gazetesi diğer gazetelerden ayrılmaktadır, ancak; buradaki köşe yazılarında kadının yaşadığı sorunların ve cinsiyetçi yaklaşımların sorumlusu olarak sistemin bozukluğu gösterilmiş, kadınların ev içinde ve toplumsal yaşamda sömürüldüğü sıklıkla belirtilmiştir. Bu durum kadınların temel haklarının sistemin değişmesine bağlı olarak onlara verileceğini ifade etmektedir. Yani kadınların kurtuluşunun sınıf mücadelesine bağlı olduğu görüşü Birgün'de sıklıkla yansıtılmıştır. Birgün'deki köşe yazılarında bir insan hakkı olarak eşitlik, adalet barış olguları üzerinde durulduğu gözlenmiştir. Dolayısıyla Birgün Gazetesinde toplumsal cinsiyet kavramının Marksist yaklaşım çerçevesinde algılandığı tespit edilmiştir. Ancak Birgün'de de Marksist kuramların getirdiği anlayış çerçevesinde kadın 
sorunları sistemin değişmesi gerekliliği üzerinden ertelenmiş bir mesele olarak köşe yazılarına yansımıştır.İslami yönelimli olarak bilinen Zaman Gazetesinde; kadının, dini söylemler doğrultusunda tanımladığı ve bu konumda gördüğ̈u tespit edilmekle birlikte bu gazetede cinsiyetçi önermeler kullanıldığı görülmüsstür. Gazete yazarlarının toplumsal cinsiyete ilişkin kuramlardan toplumsallaşma kuramına uygun olarak kadın erkek arasındaki farklılıkları açıkladığı tespit edilmiştir.Bunlar dışında kadının ev içinde ya da dışında cinsiyeti dolayısıyla karşılaştığı sorunlar üzerinde durulmamıştır ya da görmezlikten gelinmiştir.

Din ve kadın konusunun en çok Zamanda işlendiği gözlenmiştir. Zaman yazarları, kadının temel sorunu olarak türbanın yasaklanmasını göstermişlerdir. Diğer üç gazetede ise dine dayalı yaşamın kadınlar üzerinde baskı oluşturduğu fikri yer almıştır.Yazarlar kadınları dini yaşam kalıplarıyla sınırlandırmanın esas olarak erkek egemenliğini sürdürmek için yapıldığı temelinde birleşmiştir. Radikal de dikkat çeken nokta, dini uygulamaları şiddetle eleştirmeleri olmuştur.Örneğin toplumsal yaşamda kadınlara ev içi sorumluluklar ve eşle olan ilişkiler konusunda din eğilimli öğütler verilmesi rahatsızlık veren bir durum olarak yorumlanmıştır. Müslüman toplumların geri kalmıs olmasının nedenini kadınların bu tür toplumlarda yaşadıkları cinsiyetçi yaklaşımlarla karşılaşmaları olduğu vurgulanmıştır.

Kadının medyadaki algılanışına ilişkin eleştirilerin ise en çok Zaman Gazetesinden geldiği tespit edilmiştir. Zamanda medyada özellikle reklamlarda kadının cinsel obje yapıldığ 1 üzerinde durulmuş, ve bu durum açık bir biçimde eleştirilmiştir.Öte yandan Zamanda kitle iletişim araçlarının insanları şekillendirdiği vurgusu yapılmıştır. Bu noktada medyada kadınının aşağılandığ 1 cinsel obje olduğuna ilişkin mesajının daha çok kadın yazarlar tarafından verilmiş olması dikkat çekmiştir. Hürriyet, Radikal ve Zamanda medyada kadın olgusu kadın yazarlar tarafından ele alınmış eleştirilmiştir.Bununla birlikte dört gazete de medyanın eğitim işlevini bulunduğunu o yüzden dikkatli yayın yapılması gerektiği mesajını vermiş olması da dikkat çekici bir bulgu olmuştur.

Köşe yazarlarının kadın haklarına ilişkin söylemleri, kadın hareketlerini köşelerinde konu etmeleri; okuyucuyu toplumsal cinsiyet eşitliği noktasında bilinçlendirme bakımından önem taşımaktadır. Ancak incelenen gazetelerden Zaman Gazetesinde, konuya ilişkin bir bulguya rastlanmazken, diğer üç gazetede de bu tema geniş yer bulmamıştır. Hürriyette olduğu gibi Birgün Gazetesinde de; kadınların kendi haklarını koruma noktasında birer özne olması gerektiği, bu temanın ana mesajı olmuştur.Radikalde ise kızların eğitimine yönelik kampanyalar, eğitim projeleri üstünde durulmuş, eğitimle bilinçlenme sağlanacağı fikri üzerinde durulmuştur. 
Sonuçta Hürriyet, Radikal, Birgün ve Zaman gazetelerinden elde edilen bulgular; bir kitle iletişim aracı olan gazetelerin, toplumdaki cinsiyetçi kalıp yargılara paralel söylemler içerdiğini ortaya koymuştur. Bu tür söylemlerin engellenmesi için cinsiyet eşitsizliğini pekiştirici nitelikteki siyasaların değiştirilmesi, medyada kadınların istihdamının artırılması, özellikle karar mekanizmasına katılımda kadınların söz hakkının artırılması, kadın eğitiminin desteklenmesi için ulusal ve uluslar arası boyutta çeşitli kurum ve kuruluşlardan ekonomik ve siyasi destek sağlanması gibi önlemler alınması sağlanabilir.Bunun yanı sıra köşe yazarlarına toplumsal cinsiyet eğitimi verilerek kadın erkek eşitsizliği konusunda duyarlılık kazanmaları ve eleştirel medya okuryazarlığı konusunda verilen eğitimlerin yaygınlaştırılması önerilebilir.

\section{KAYNAKLAR}

Ayhan, Ahmet Turan (2001).'Gerçeği Gizleyen Putlar: Medya', Karizma Dergisi, cilt: 8, ss: 57-62.

Bek - Gencel, Mine; Binark, Mutlu (2000). Medya ve Cinsiyetçilik. Ankara: Ankara Üniversitesi Kadın Sorunları Araştırma ve Uygulama Merkezi Yayını.

Connell, Robert William (1998).Toplumsal Cinsiyet ve İktidar, İstanbul: Ayrıntı Yayınları.

Çotuksöken, Betül(2006). 'Türkiye'de Kadın Olmak' Web: Akademik.maltepe.edu.tr/ betulc/ Erişim tarihi: 2.12.2007.

Doltaş, Dilek (1995).'Batıdaki Feminist Kuramlar ve 1980 Sonrası Türk Feminizmi “Türkiye'de Kadın Olgusu”, Yayına hazırlayan: Necla Arat, İstanbul: Say Yayınları.

Dökmen, Y.Zehra(2004).Toplumsal Cinsiyet.İstanbul:Sistem Yayınc1lık.

Geray, Cevat (2002). Halk Ĕgitimi, Ankara: İmaj Yayınevi.

Göle, Nilüfer (2004).Modern Mahrem: Medeniyet ve Örtünme, İstanbul: Metis Yayıncilik.

Gürses, Fatma (2003). Medya ve Kadın Öğretmenler. (Türkiye'de Yazılı Basında Kadın Öğretmenin Temsili). Ankara: Eğitim-Sen Yayınları.

Hartmann, Heidi. (2006). Marksizm'le Feminizm'in Mutsuz Evliliği. İstanbul: Agora Kitaplığ1.

İnal, Ayşe (1996).Haberi Okumak, İstanbul: Temuçin Yayınları.

Karasar, Niyazi (2008).Bilimsel Araştırma Yönetemi.Ankara: Nobel Yayınları, 18.Basım.

Kazemi, Farhad (2004). Toplumsal Cinsiyet, İslam ve Politika, çev. Didem Özalpat, Ankara Hukuk Fakültesi Dergisi. cilt:53, sayı:1 (2004) ss: 251268. 
Lindeman, C.Eduard (1969).Halk Eğitiminin Anlamı, çev.Celal Şentürk, Ankara: Milli Eğitim Basımevi.

Lowe, John (1985).Dünyada Yetişkin Eğitimine Toplu Bakış, çev.Turan Oğuzkan, Ankara

Neumann-Noelle Elisabeth(1998).Kamиoyu, Suskunluk Sarmalı. Ankara: Dost Kitabevi Yayınları.

Schroeder, Süheyla Kırca (2007). Popüler Feminizm, Türkiye'de ve Britanya'da Kadın Dergileri, İstanbul: Bağlam Yayıncılık.

Unat, Nermin Abadan (1995).'Kadın Araştırmalarının Neden, Amaç ve Kapsamı' Türkiye'de Kadın Olgusu) içinde, İstanbul: Say Yayınları.

Winship Janise (1980). 'Sexuality for Sale', (der.) Hall S. vd. culture, media, Language, Hutchinson.Londra.Aktaran Ayşe Saktanber, Türkiye'de medyada kadın: serbest, müsait kadın veya iyi eş, fedakâr anne, içinde (1980'ler Türkiye'sinde Kadın bakış açısından kadınlar) yayına haz. Tekeli şirin (1993), İstanbul: iletişim Yayınları. 